finding considerably more spontaneous mutations than all other Drosophila workers together. He made it his duty to determine the place, in the genetic scheme, of all the changes which he found, and continually to refine upon the conceptual system which they constituted and which, as his work helped to prove, represented the actual material plan of the germ plasm. It was in the course of this systematic testing that he happened, one after another, upon that series of unusual cases which proved to be, not mutations in individual genes, like the rest, but abnormalities of whole chromosomes, of chromosome parts, and of entire sets of chromosomes, and which served as the starting point of most of our modern knowledge of 'chromosome mutations'.

The first of these great contributions of Bridges to genetics was his discovery of non-disjunction, first of the sex chromosomes $(1913,1916)$ and later of the fourth (1921), together with his working out of its mechanism and of its cytology. It was the striking visual demonstration of the chromosome theory of heredity thus provided which first convinced Bateson, and along with him many other sceptics, of the truth of this theory as a whole. But at least equally important, in its actual pushing forward of our genetic knowledge (as distinguished from the confirmation of things for which cogent evidence really existed already), was his discovery and working out of cases of deficiency (1915, published 1917, et seq.) of a part of a chromosome, and of the first translocation (1918, published 1919, et seq.). His discovery of triploids (1921), with its proof of the then disputed idea that sex determination depends upon the relative doses of interacting genes, opened up new chapters in our understanding not only of sex determination but also of the manner in which genes in general exert their effects. While in the interpretation and in the planning of the attack on all these cases he enlisted the forces of the whole group of Drosophila workers, his initial discovery of the cases, his recognition of the fact that their peculiarities were such as to make them worthy of special studies, and his exemplary prosecution and presentation of these studies themselves, were direct results of that combination of assiduity and intelligence, of method, of painstaking attention to detail, and of following up all clues to their logical conclusions, which always characterized Bridges' manner of working.

In recent years, applying this same meticulousness to the cytological investigation of the giant (multiple) chromosomes of the salivary glands, the possibilities of which had been revealed by Painter (1933 et seq.), Bridges, working with renewed vitality on this new branch of the old trail, succeeded in developing amazingly upon the technique and the exactitude of the results ; he invented (independently of Koltzoff) the 'polytene' explanation of these chromosomes, and made the important discovery that the remains of 'duplications' produced in past evolution by a process of chromosome breakage and reattachment of parts, similar to that occurring in observed translocations, could still be detected by direct observation in the chromosomes normal to the species. This, and the gathering together and systematization of the multi- tudinous extant material on Drosophila mutations and technique, in the "Drosophila Information Service", constituted the invaluable work upon which he was still engaged at the time of his death.

Bridges suffered more than most men of science from the hardships attendant upon the following out of new trails of thought and action both in his scientific work and in general. But, though in a sense single-minded, he preserved his early freshness of attitude, boyish enthusiasm, sunniness of character and friendliness. $\mathrm{He}$ did not let scientific rivalry interfere with his personal friendships, and threw himself into them whole-heartedly and without suspicion. Combined with calculation, he preserved a charming naiveté. He was most patient and kind in helping less advanced workers. He was engrossed in his work to a point of absent-mindedness which became a byword to others. His personality was such that it is likely to pass into legend. But his work will undoubtedly form a solid indestructible part of the basic structure of all future biological science.

H. J. MULLER.

\section{Mr. M. A. Phillips}

Mr. Montagu Austin Phrulips, the well-known lecturer on natural history subjects, died on January 11, aged fifty-nine years. $\mathrm{H}_{\Theta}$ had been for many years associated with the British Museum (Natural History) where he acted as a deputy guide-lecturer. Originally he assisted the late Mr. J. H. Leonard, the first official guide-lecturer to be appointed at the Museum, and after Mr. Leonard's death in 1931 he carried on the whole of the guide work until the appointment of the second official guide-lecturer, Miss Mona Edwards, in October 1932. From that time onwards, Mr. Phillips acted as an auxilliary lecturer at the Museum, and was so engaged up to the close of last year, when ill-health caused him to abandon his work. In addition to lecturing in the Museum he had, for many years been a well-known lecturer at schools, societies and field-clubs and travelled extensively in connexion with this work. In his lectures, Mr. Phillips had a certain charm of manner which made even the dullest of subjects attractive to his audience, whether it was a large audience at a 'sit-down' lecture or a small group of people in the Museum Galleries.

Mr. Phillips was educated at King's College, London, and was a fellow of most of the senior scientific societies, including the Linnean, Zoological, Geological, Geographical and Royal Entomological Societies; he was in addition a member of the British Ornithologists' Union and was associated also with the Royal College of Organists, being an enthusiastic musician. GuY Dollman.

Dr. C. J. Gahan, keeper of the Department of Entomology in the British Museum (Natural History) during 1913-27, on January 21, aged seventy-seven years.

Prof. A. Sauveur, professor of metallurgy in Harvard University during 1906-35, aged seventysix years. 